\title{
Resurrecting 'Metaphor' inside the EFL Poetry Classroom: a Nudge towards an Integrated-Model
}

\author{
Amina Bouali \\ Department of English, Faculty of Foreign Languages \\ Oran University, Oran, Algeria
}

\begin{abstract}
:
'Metaphor' captures the zeitgeist of the 21st Century for reaching a climactic scene on the stage of cognitive linguistics, literary studies, and Second Language (L2) teaching. Important though, in Algerian English as Foreign Language (EFL) literature classrooms, metaphor plays a peripheral role in education, as it scarcely appears either as part and parcel device in literature analysis or as a means for strengthening the understanding of poetry. However, even in those literary spaces where it visibly manifests itself, learning the metaphoric language does not touch a chord with the learners. The persistent issue is that many Algerian instructors are still employing threadbare, transmissive modes of instruction that fail deceptively to reach satisfying scholarly ends. In this sense, the fulcrum aim of this study is to explore the effectiveness of repositing metaphor inside the poetry curriculum. Correspondingly, it proposes the integrated-model as a state-of-art teaching framework. The primary question that this study seeks to answer is whether teaching poetry via an integrated approach may act as a stimulus for enhancing students' Metaphoric Competence (MC). The secondary subsidiary endeavour is to diagnose the different intricacies that the learners confront along that process. Guided by these incentives, the researcher has carried an empirical study (pre/posttest) with forty-first year EFL Algerian students from Tlemcen University using four poems as evaluative materials. To analyze the effectiveness of the experiment using SPSS, the inquirer has opted for the PairedSamples t-Test to check whether the paradigm shift in the same group of participants' grades is statistically significant or not. Substantially, this study reveals that the implementation of an integrated framework to instruct poetry provides a springboard for remarkable betterments in the area of MC. This progress is evidenced by its ability to revitalize the learners' cognitive potentials to comprehend, interpret, and evaluate conceptual metaphors embedded in poetry. In an unfavourable note, this study has also dropped the veil on some language difficulties that the students face in the course of metaphor analysis, that stem mainly from the low exposure to the target language (TL), and the poor engagement with the different literary modes of expression. Finally, for the hope of honing (MC) inside the Algerian EFL classes, it is fervently recommended that the teachers assist their learners actively in well-defined figurative-oriented assignments that focus on raising the awareness of the L2 conceptual mapping. Technological aids are also a solicited constructive teaching material that may make poetry draw a new breath of life inside the classroom and beyond.
\end{abstract}

Keywords: metaphor, EFL literature classroom, the integrated approach, metaphoric competence, poetry curriculum

Cite as Bouali, A. (2020). Resurrecting 'Metaphor' inside the EFL Poetry Classroom: a Nudge towards an Integrated-Model. Arab World English Journal for Translation \& Literary Studies 4 (2) . 187-220.

DOI: http://dx.doi.org/10.24093/awejtls/vol4no2.15 


\section{Introduction}

The subject of metaphor has perceptibly ionised into a fascinating sublime, of which ineffable allure continues to mesmerise a never-ending chain of ambitious scholars in the field of linguistics, psychology, and cognitive linguistics from the time immemorial to the present day. Its current strength is fundamentally inculcated from a contemporary cognitive reflection on metaphor, with a faithful reference to Lakoff and Johnson (1980), which demonstrates vividly that this figurative trope is not a chiefly poetic gimmick or a rhetoric device peripheral to the language use (Kirby, 1997). In essence, it is a rather extraordinary cognitive phenomenon that nurtures our natural reasoning and informs people's actual perception of the world. According to Lakoff and Johnson (1980), metaphors are those undue concepts which we 'live by'; they are "pervasive in everyday life, not just in language but in thought and action" (p. 4). What is strikingly distinct about the contemporary theory of metaphor is its ability to capture the researchers' attention to the omnipresence of metaphor in the language, its ultimate ascendancy over everyday dynamic thoughts. Importantly still, these kinds of nourishing perspectives have helped revive the subject of metaphor inside academies, when many perceived views start to consider the teaching of metaphor a sine qua non for the acquisition of instructive knowledge and the heuristic discovery of the language (Holme, 2004). Advantageous still, the magnificence of cognitive theory also resides in how it makes a new beam of sense glitter down upon the subject of 'Poetic Metaphor', which finds plenty of room in impressive studies advanced by Lakoff and Turner (1989) and Gibbs (1994). These researchers maintain that most metaphors - which proliferate abundantly in poetry - are not strokes of genius, wit, and elusiveness. Instead, they embody a way to communicate the same conceptual mappings inherent in human thoughts but with a different ornamented style (Gavins \& Steen, 2003; Stockwell, 2005). Gibbs (1992, 1994), on his part, explains that the elaboration of metaphor undergoes three central processing, namely comprehension, interpretation, and appreciation. In an English Language Teaching (ELT) context, Gibbs' theory reigns supreme, especially in Cameron and Low (1999), and Littlemore's (2001) study on metaphoric competence that follows nearly the same lines of figurative understanding sketched by Gibbs. According to Littlemore (2001), there are four tangled facets of MC that signify the capacity to acquire, to create, and to interpret metaphors during a short time speed. However, the most substantial surge towards promoting the students' figurative thinking emanated abundantly from poetry (Cameron, Candlin, \& Sarangi, 2003). Undoubtedly, exploiting authentic poems in an EFL classroom is said to be "a powerful change agent by developing language learners' intercultural awareness while at the same time nurturing empathy, a tolerance for diversity and even emotional intelligence" (Littlemore \& Low, 2006, p. 99).

Given to all these views, one can think of a poem as a rich field appropriate for growing some fertile ideas and effective strategies to enhance metaphor learning inside classes. However, teaching poetry inside Algerian EFL classes is not as vital as in elsewhere. Such a parlous state is possibly attributed to the fact that many Algerian students still feel haunted by the eldritch mechanism of English poetry, which encounters them to a new language that is almost sophisticated, archaic, and highly symbolic. In the case of Tlemcen, the studies on poetry are also agonizing, for they are lucidly marginalized from the mainstream curriculum. However, despite this state of malaise, poems are sometimes integrated into the umbrella field of literary studies 
prescribed for different grades, especially the first and the third year. More involving, the students in the first year are supposed to delve into the techniques and the mechanism of English poetry exploring thoroughgoing the poems of the mastermind of English poetry, William Shakespeare, whose sonnets continue to hold an enduring value for some centuries ahead. Unluckily, poetry is dislodged from the second-year programme. Nevertheless, some teachers of literature still prefer to integrate some authentic poems in the curriculum, such as William Blake's "Chimney Sweepers," that is invaluable teaching material used to show the phenomenal revival of poetry in the age of Romanticism. On the other hand, literature syllabuses of the third year also incorporate very few poetic works that go back to twentieth-century Modernism, best represented by some great minds of the time like W. B. Yeats and T. S. Eliot. All in all, the teaching of poetry in the department of English looks in an unhealthy state, and it seems, it is still struggling hard to survive.

Guided by this reality, and in the light of all previous accounts, the current study is an attempt to examine the effect of teaching poetry on the first year EFL learners' MC at Tlemcen University (Algeria). The study strives, concomitantly, to shine a flashlight on the challenges coming before the learners while trying to cut across the literal boundaries of the poetic works. To reach this goal, the researcher has proposed to use the integrated-model as a teaching framework, which is a fashionable and very engaging methodology of instruction. However, to generate an idea about this methodology of teaching, it is significant to highlight its mechanism, the instructive techniques, and the objectives underlying its actively-oriented purposes. Substantially, the implementation of the integrated approach to teaching literature in an EFL context has been first proposed by O'Brien (1999) then re-planned for a more ambitious scale by Savvidou (2004). It is proper "a linguistic approach which utilizes some of the strategies used in stylistic analysis, exploring texts, literary and non-literary from the perspective of style and its relationship to content and form" (Divsar \& Tahriri, 2009, p. 108). Technically speaking, the integrated model suggests the conglomeration of three models of instruction: the language-based model, literature as content or cultural model, and literature as a personal growth model (Carter \& Long, 1991). Its purpose is to shape a cutting edge teaching methodology that is apt to cater to all the learners' needs, styles, and tastes. In this sense, it is vital to bridge the chasm between the learner, the target culture, and the reader's stamp of engagement with the poems under scrutiny.

In that flash of illumination, the cornerstone of this study is to gauge whether -and roughly to what extent - teaching poetry through an integrated framework may enhance the intermediate EFL learners' metaphoric competence, focusing on three building skills; metaphor comprehension, 
interpretation, and evaluation. In line with this purpose, the research will shed light on some of the main intricate difficulties that hinder the participants' metaphor understanding processing.

To reach these ends, the empirical study carried out along the lines of this paper targets to answer the following research questions:

(1). To what extent teaching poetry via an integrated approach can foster the undergraduate EFL students' metaphoric competence at the University of Tlemcen?

(2). What are the unsettling limitations that intimidate learners while dealing with metaphors in poetry?

To cater for healing answers to the questions expressed little above, the research proposes the following hypotheses:

(1). Since the integrated approach puts stress on all the possible dimensions of the language delineating the stylistic, cultural, and the enriching aspects of the text, implementing this model, as the researcher presumes, may cater to better results. It sounds reasonable to assume that the fusion of different perspectives, beliefs, and values embedded in the poem is likely a capstone for metaphor conceptual reasoning, since metaphor itself, cannot be grasped in isolation, and needs to be re-posited in a socio-cultural context. From another vantage point, the integrated approach may involve the learners in varied strategies and procedures that attempt to crack down many fences between the students- as implied readers- and the language of the poetic text.

(2). It is hypothesized that poetic metaphors would open a can of worms inside classes. Under this belief, the learners are supposed to get stuck on many difficulties along the process of metaphor entailment. The contention in this study is that many of the students are not wellequipped to deal with polished metaphors in poetry. Besides, the beginners are less familiar with the target culture of the author, and even worse, they lack the exposure to literature that inculcates the self-confidence in them to engage with more complicated language patterning. Therefore, though some metaphors will not be confusing for the participants to deal with, others will expectedly slip through the net.

In this spirit, this paper will anchor on Gibbs' theory of metaphor understanding with a firm reference to Littlemore's (2001) conception of MC, and practically, the study would draw on the procedures and the strategies of the integrated model that seems to mesh well with the stages and However, before delving into the empirical study of this research paper, it is immensely important to a bird's eye view on the main definitions of the term 'metaphor' and its possible applications in the EFL literature classrooms.

\section{Metaphor Conceptualized (A Brief Literature Review)}

The concept of metaphor is defined from a welter of perspectives. Etymologically speaking, a metaphor has its deepest roots back to the ancient Greeks who utilize the term to refer to the act of transfer between what is called the 'tenor' and the 'vehicle'(Sepp \& Embree, 2010). These oldest vestiges of studies on metaphor left by the Greeks are all grounded in Aristotle's book of Poetics that offers sui generis assumptions on the poetic function of metaphor and its aesthetic 
impact on the readers, paving the path to what becomes known as the traditional Analogy Theory. So according to the champions of this view, metaphor signifies a rhetoric device or embroidering tool to the language crafted carefully to embellish the great works of art (rhetoric); the poetic pieces of writing in the first place (Ortony, 1993). Strongly then, Aristotle's traditional view on metaphor and its rhetoric influence within a poetic discourse could build a solid pedestal upon which a large body of research has based. In the same account, the process of metaphoric thinking has been considered an artistic proficiency that is a tough thing to come by (Garrett, 2007; Kirby, 1997). It is said to be the consummation of grotesque poetic genius and plenitude of mind that only endowed (master) writers can grip in the palm of their hands. "A good metaphor," as claimed by Aristotle, "is the one thing that cannot be learnt from others; and it is also a sign of genius, since a good metaphor implies an intuitive perception of the similarity in the dissimilar" (Poetics 1459a in Lossi, 2010, p. 211). Not surprisingly, the Aristotelian perspective stays unrivalled and consistent for a considerable time. It has translated into what becomes conventionally known as the comparison theory of metaphor. In time, the perception of metaphor, which falls basically under semantic, pragmatic, and cognitive levels of understanding, has witnessed a metamorphosis in meaning from the implied comparison (Aristotle (1924) into a conceptual cross-domain mapping (Lakoff \& Johnson, 1999)).

From a linguistic vantage point, the metaphor has been described earlier as a flagrant phenomenon of the language system that relies heavily on similarity (Gentner, Holyoak, \& Kokinov, 2001; Holyoak \& Thagard, 1995). It also means the substitution of a 'proper' expression with another (Ortony, Reynolds, \& Arter, 1978), in that to generate a 'fictitious' signification to reality (Ricoeur, 1978). Under the traditional theory, the hidden meaning of metaphor in a sentence is grasped by the 'analogical resonance' of meaning that springs at the temporal time when words harmonize with their associative concepts. In this sense, metaphor has been defined by Paul Henle (1958) as "[A sign that is] used in reference to an object which it does not denote literally, but which has certain properties that its literal denotandum has" (in Wheelwright, 1962, p. 74). Analogy theory had offered later a reliable source of inspiration to two aspirational views, namely the 'tension' and 'interaction' theory advanced respectively by Richards (1936) and Max (Black, 1962). In his treatment of metaphor, Richards (1965) suggests that this figurative device does not function only through parallelism and those commonalities that emanate directly from the interplay, or fusion (see Avis, 1999), that occurs between the topic and the vehicle. Instead, metaphor is created out of the paradoxes of concepts association that instigate a kind of 'tension' or 'incompatibility' between the topic and the vehicle. This tension may evoke thereby a fresh metaphor to come to life (Bilsky, 1952).

Stepping into Richards' shoes, Max Black advanced, in 1962, the interaction theory that became so far one of the most influential theories in the semantic study of metaphor. Centre to this assumption is that all metaphors create an interrelated complex of concepts that Black refers to as a 'system of associated commonplaces.' This conceptual network embodies a wealthy treasury of criss-cross connotations and meanings that are close to the primary and the secondary subject of a metaphor. This latter can create ad infinitum a change in the meaning of words regarding their position and function in a particular sentence. Surprisingly at the end of the interpretation process,

Arab World English Journal for Translation \& Literary Studies 
the prodigious number of meanings that associate with a word provoking interaction between the topic and the vehicle will stir something novel to sprout; an innovative thought which construal is a less conventional task. (Berrada \& Jahfa, 2011)

In opposition to the semantic view of metaphor, some researchers, like (Levinson, 1983; Searle, 1979) consider metaphor as a pragmatic process, whose meaning couches in a given context of an utterance, and it is by any means context-free as Cohen (1993) and Katz (1981) forcefully aver. Metaphor, to this contention, takes place as a part of a speech-act shared by different members of a social community or a cultural background (Searle, 1979). In the same regard, other champions of the pragmatic view categorize metaphor as a linguistically anomalous and semantically deviant figure of speech. As Grice (1975) claims: "metaphor results from a violation of the maxim of truthfulness" (p. 20). Accordingly, one would realize that an expression like 'the stone died' is metaphorical only if it is identifiable by its patent falsity. In the same account, Grice (1975) suggests that the meaning of an utterance depends very much on the "conversational implicature" that is produced as a result of the cooperation that occurs between the hearer and the listener within a conversation. Therefore, the target of conventionality is assured to realize if the talk obeys to the four maxims of literality, notably 1/ Quantity (informative); 2/ Quality (truthfulness); 3/ Relation (relevance); and 4/ Manner (to be brief). Otherwise, if an utterance flouts these maxims, it is likely intended metaphorically.

From a cognitive vantage point, the advent of the contemporary theory of Metaphor fathered by Lakoff and Jonson (1980) becomes a pièce of résistance that marks a quantum leap in the systematic understanding of metaphor and cognition. The gist of this contention rests on the premise that metaphors are part and parcel elements of the language that inform our conceptual mapping, and are not, or not, exclusively poetic or subsidiary parts of speech. In this vein, Lakoff and Johnson (1980) emphatically aver that "our ordinary conceptual system, in terms of which we both think and act, is fundamentally metaphorical in nature" (p. 4). For instance, most conceptual metaphors, like ARGUMENT IS WAR, IDEAS ARE FOOD, LOVE IS A HEAT, LIFE IS A JOURNEY, to name but a few, are not random analogies, but abstract schematic thoughts very pervasive in language and thoughts. As demonstrated by Lakoff and Johnson (1980), the inner power of schematic metaphors lies in their ability to "structure what we perceive, how we get around in the world, and how we relate to other" (p. 4). Fundamentally, the cognitive theory of metaphor has added an extra flavour and profundity on the conceptualization of the figurative language by shaping its pivotal role in reconfiguring the thinking habits of mind (see Gibbs \& Steen, 1999; Katz, Cacciari, Gibbs, \& Turner, 1998; Ortony, 1993). Given to the figurative mental functioning, Bishop and Starkey (2006) state emphatically that "metaphors don't simply reflect the way we look at the world, they can actually shape that process, and that shaping is intimately intertwined with how we remember the world" (p. 114). By the same token, Charteris-Black (2004) exalts the authenticity of metaphor as a product of the mind that "originates in human creativity" (p. 3). In their part, Cortazzi and Jin (1999) go further than that by delineating metaphor as a bridge to the reality that "links and comprises the known and the unknown, the tangible and the less tangible, the familiar and the new" (p. 149). Apart from all those diffracted spectra of attitudes cast on metaphor over the last two centuries, which turned it, after a fashion, into an enthralling topic

Arab World English Journal for Translation \& Literary Studies 
for debate, what concerns one the most along the pages of this study is how poetic metaphors matter in EFL literature classrooms.

\section{Poetic Metaphor}

"Our minds are 'embodied' not just literally but also figuratively."

(Stockwell, 2005, p. 4)

The extension of cognitive-linguistic metaphor to the field of cognitive poetics could revive great curiosity about poetic metaphor, which has rapidly pull at the heartstrings of many researchers who grow much enthralled by the poetics inherent in human being's minds, like Gibbs (1994); and Lakoff and Turner (1989). In their most influential book; More than Cool Reason: A Field Guide to Poetic Metaphor, Lakoff and Turner (1989) pinpoint the ubiquity of poetic metaphors in everyday talks and interactions. They both believe that the images that the poets generally create are not extraordinary phenomena of the language. Rather they signify natural and automatic performances of the ideas that are all-pervasive in human mental reasoning. As they both elucidate that "[metaphor] is indispensable not only to our imagination but also to our reason. Great poets can speak to us because they use the modes of thought we all possess. (Lakoff \& Turner, 1989, p. 4)

Very akin to this view is that of Gibbs $(1994,2008)$, who also underlines the cognitive potential of poetic metaphor that does not necessarily reside in its extraordinary level of absurdity, ambiguity, or oddness intended to create new blind spots in the poem. On the contrary, creative act manifests itself in those various polished choices that the poets manipulate cautiously to speak about pretty the same conventional conceptual associations between source and target domains already hardwired in human thought. In this fashion, poetic metaphors attest to a natural process of figurative thinking, which originates in the same conceptual reasoning by which people interact and make sense of the world. "What poets primarily do, again, is not create new conceptualizations of experience but talk about metaphorical entailments of ordinary conceptual mapping in new way" (Gibbs, 1994, p. 7). For instance, Emily Dickenson's verses 'the only Ghost I ever saw/ was dressed in Mechlin' depict death in such a startling novelty that surpasses the imagination of any ordinary person. Nonetheless, the scary image of death that she strives to personify through the invisible dark shadow seems to represent a familiar conceptual mapping that people already possess in mind embodying (DEATH as A GHOST).

By the same token, Haley (1988) draws the researchers' attention to the disparities that lie between natural analogies and poetic metaphors. By extrapolating his speculation from Chomsky, Haley (1988) avows that poetic metaphor "is a matter of performance (use of knowledge) rather than of competence (kind of knowledge)" (p. 4). Explained in another way, there is a difference not in the kind but the degree of awareness of the semiotic functions of words; signs and images that the poets are undoubtedly more sensitized to than the non-poets. In this way, the poets are more apt to put implicit objects more innovatively. These objects, however, would stay vague until the bard demystifies them before people's eyes, and later become familiar to them as if to the manner born. Involving still, Peter Crisp (2003) suggests the penetration of poetic metaphor through the prism of blending theory hypothesized by Fauconnier and Turner (2002). The gist of

Arab World English Journal for Translation \& Literary Studies 
this thesis is that the listener/reader goes through an 'online' cognitive processing' in his understanding of poetic metaphors. This moment-by-moment inference involves him to call for a new mental space to facilitate the association between the source(s) and the target domain, though it could belong to neither. According to Fauconnier and Turner (2002), the mental spaces stand for those "small conceptual packets constructed as we think and talk, for purposes of local understanding and action" (p.136). Stepping on Fauconnier and Turner's shoes, Crisp (2003) goes for a fourth mental space that he calls the generic space created by the fusion that occurs between the target domains, the source domains, and the blended space. Ultimately, this fusion allows a new metaphor to come into existence that looks brimming with ingenuity and resourcefulness. All in all, arguments of the former kind have called the theorists' attention to the significance of the poetic uses of the language in the way humans behave, communicate, and think, and also in the way people learn the target language (TL).

Metaphor, Literature, and the EFL Classroom: A Shove towards Metaphoric Competence (MC) Literature survives after all metaphorically - say a poem, a novel, or any work of art. All literary forms cannot escape flouting the standard norms of the language, constructing a new-fangled image schematized in mind. This is to say that all the works of art, not least poems, are metaphorical in the genes. As a result, it is hardly possible to engage with a rhetorical discourse without delving into the depth of the symbolic images, that are a master key to penetrate, or even perhaps, to make a new light of understanding shine on the blind spots of the literary text(s). In an EFL teaching context, strident voices solicit more earnestly for consolidating the position of metaphor in language learning, yet, little of their echo could reverberate off the chart in the field of applied linguistics. For instance, Low (1988) has portrayed the paramountcy of conceptual metaphor in the vast world of praxis. He eulogizes the building role of metaphor in mapping many language-based assignments, and also its significance in extending the breadth of awareness of the phenomenal uses of the language (see Lazar, 1996). In the same vein, Zheng and Song (2010) advocate strongly that metaphor in education sustains the learners with many insightful clues that help them unravel the mysteries of the language that featured in different contexts and inspire them new tricks for understanding. However, the metaphor is very often accused of clouding the issue of transparency and the discernment of literary taste by presenting sloppy and odd ways of thinking (see Green, 1993). But many of its appreciators, who are in the majority, show the lofty ideal of integrating metaphors in the classrooms to help the learners get outside the familiar world of the language by experiencing things that are full of novelty, inspiration, and discovery. For instance, Petrie and Oshlag (1993) claim that metaphor - regardless of all its variety of types and functions -it "enables one to transfer learning and understanding from what is well known to what is less well known in a vivid and memorable way, thus enhancing learning" (p. 580). Better still, the researchers often argue that the implementation of elicited metaphors at schools is a powerful strategy for illuminating the implicit beliefs, attitudes, and behaviour of the instructors (Wan \& Low, 2015, p. 39).

As related to literature teaching, poetic metaphors are considered motivating sources of knowledge that have plenty of aesthetic, cognitive, and cultural effects. Substantially, reading a literary discourse through the lenses of metaphor enables the close diagnosis of the language,

Arab World English Journal for Translation \& Literary Studies 
whereby the learners appreciate the register, the diction, and the tone of the text (Littlemore \& Low, 2006). On a more favourable note, Picken (2007) persuasively supports the view that metaphor that resides in poetry or a novel possesses some traits that have a strong potential of warming our hearts and enlivening our minds by keeping the text fresh and always on the move. On the same account, Charteris-Black (2004) throws light on the emotional effect of metaphor, which he asserts, is a potent and overwhelming tool of persuasion used in political and rhetoric discourses to convince people to look to the world with different eyes. As he elucidates, "metaphors are usually influential because they persuade us of certain ways of viewing the world. I hold the belief that a better understanding of language is the basis of creating a better society" ( Charteris-Black, 2004, p. xii).

On the scholarship stage, other researchers have made a fervent plea for (re)thinking the conceptual metaphors $\mathrm{CMs}$ at schools by considering their pro vitality and effectiveness on enhancing the learners' MC (Cameron, 1999; Littlemore, 2001) -overlapped later under the umbrella-terms 'figurative language competence' (Littlemore \& Low, 2006). From another pro scale, teaching metaphors promotes the learners' communicative language proficiency drawing on Hymes (1972). However, as a newly coined concept, ' $\mathrm{MC}$ ' is a slippery term that might denote different things for different applied linguistics. As for Stern (2000), it proper entails two categories of expressive mastery; one is an offspring of semantic competence that implies the speaker should possess a 'Knowledge of Metaphor'; i.e., "knowledge that includes a stock of concepts that constitute the linguistic or lexical meanings -literal meanings" (p. 8). Adding to 'Knowledge by Metaphor,' which refers to the speaker's ability to interpret metaphors, not literally, but metaphorically. In brief, Stern (2000) describes the true characteristics of a metaphorically competent speaker who should know "how to generate metaphorical expressions given her knowledge of the expressions F to be interpreted metaphorically" (p. 198). On that qualification, the identification of metaphorical utterances here is always context-dependent. Analogously, according to Low (1988), a competent learner of metaphor is distinguished by his ability to (a) to build reasonable meaning, (b) the ability to pick up the intentions of the speaker out of a metaphoric utterance, (c) and the potential to discriminate or to recognize whether a sentence is meant literally, figuratively, or from both 'hedges,'(d) also the ability to cope with invented and new metaphors, (e) to be sensitive to the necessity to adapt metaphors according to the social sector one is dealing with, (f) to be aware of several levels of metaphors, $(\mathrm{G})$ and finally to be apt to link vague statement coherently in the language.

More painstakingly elaborated research on MC is the one presented by Littlemore at sunset of the twentieth century. Her deep understanding of this area of concern covers four crucial elements for assessment, that are resumed as follows: (1) the ability to produce original and unconventional metaphors, (2) the fluency in drawing a multiplicity of interpretations for the same metaphoric expression, (3) the capability to think of tangible meanings for creative metaphor(s), (4) and lately, the ability to elaborate metaphors quickly and even under pressure. Plausibly, Littlemore's (2001) stratification of the different components of $\mathrm{MC}$ seems to relate very strongly to communicative language competence, and thoroughly, to Gibbs's theory of metaphoric understanding processing that appears in many of his groundbreaking studies (Gibbs, 1992, 1994, 2008). For instance, in his

Arab World English Journal for Translation \& Literary Studies 
research paper "When Is Metaphor?" Gibbs (1992) elaborates the understanding of metaphor as "a continuous mental event that takes place in real time, starting with the first milliseconds of processing and potentially extending through long-term, reflective analysis" (p. 576). On that characterization, $\mathrm{MC}$ embodies the "ability to acquire, produce, and interpret metaphors in the target language" (Littlemore, 2001, p. 459). Equally salient, the present study will also cast a wider net on the processing of 'metaphor evaluation' in literature (poetry in particular), which fascinates several researchers, including Gibbs (2002) and Picken (2007). In the vision of Picken (2007), judging metaphor in literature can be either done from an aesthetic, or emotional perspective, or both. Aesthetically, metaphoric evaluation generally overlaps with the Aptness Tradition Theory, which asserts the assumption that to appreciate a metaphor one has to build contemplative judgments that are purely based on its aptness or aesthetic value in the context to which it belongs. In essence, Gibbs (2002) elucidates that "appreciation refers to some aesthetic judgement given to a product either as a type or token" (p. 103). For example, 'my marriage is an icebox' is evaluated in terms of the aesthetic compatibility between the word 'marriage' and 'icebox' that depicts a cold, unhappy marriage devoid of feelings.

\section{Revisiting Poetry in EFL Classroom: How Much Novelty?}

Before engaging the readers with sharp perspectives on the triangular interplay (effect) between poetry, metaphor, and the EFL classroom, it is of high saliency to start by tracing the most recent stamps of advancements in each area of concern. The meaning of this process is to appraise the degree of the pedagogical progress achieved, to draw links, and then to expose the gap. Keeping this objective in mind would make it so meaningful to touch the sensitive nerve wondering how much novelty value is characterising the actual teaching perspectives and strategies applied to meet the contemporary poetry pedagogy. Raising such a concern forces us to describe first the Scylla and Charybdis situation that poetry undergoes inside the classroom. The Scylla signifies the slippery and undecided views on the unnecessary inclusion of poetry writings inside the curriculum (Maley \& Duff, 1989; McKay, 1982; Lazar, 1996; Widdowson, 1975), leading to a Charybdis of an obscured pedagogical destination (Aydinoglu, 2013; Hall, 2015).

Hopefully, in the past two decades, many scholars show ambitious attempts to strengthen the position of poetry in education, by perceiving poems basically as the lifeline for a well-rounded literature classroom, and overall, as an enriching component in the study of the language (Antika, 2016; Khansir, 2012; Khatib, 2011). The assumptions pervading the mainstream education have emphasised its immense contributions to language acquisition and L2 learning. With this line of argumentation, some researchers claim that poems are promoting educational tools that enhance language proficiency by demonstrating the possibilities of language use, particularly phonetics, lexis, syntax, morphology, and the stylistic devices (Hu, 2010; Rodríguez, 2018). In the same vein, other common studies have highlighted the effect of using authentic poems in the classroom as a content-rich reading material, explored inside classrooms to develop the learners' productive skills, such as reading comprehension abilities, and critical reading skills (Rodríguez, 2018). On the other pro side, some researchers have strongly evinced the leading role that poetry plays at schools in honing the learners' speaking abilities, and to develop their fluent reading abilities (Deepa \& Ilankumaran, 2018; Srisermbhok, 2017; Yavuz, 2010). Besides all the stated virtues, the

Arab World English Journal for Translation \& Literary Studies 
authentic English poems in EFL classes are also considered cultural emblems replete with social ideologies and semiotic clues. Thus, introducing them to the learners may foster more familiarity with the target culture contributing to the development of their intercultural competence (Melzer, 2001).

The most recent developments in the didactics of poetry have proposed refreshingly new models of teaching that can promise educational betterments. In this context, Kellem (2009) exalts the beneficial pedagogical ends of using the Formeaning Response Approach to teaching poetry. This approach, as he strongly recommends, allows the perfect combination between the form and the inward meaning of the text, which "anchors students in the language of a poem while inviting them to express their own responses to the themes of the poem" (Kellem, 2009, p. 16). Unlike Kellem's paradigm model, the revolutionary few attempts tackling the subject of poetry pedagogy had all drawn new road maps for a student-centric methodology that could boil down to meaningful teaching practice. Most studies presently advocate the need for innovative teaching strategies that transcend beyond the walls of the text, treating the poem as a cultural testimony, a crystallisation of language structure and thoughts, a source of inspiration, and an impulse for personal involvement and creativity. Some researchers like Dutta, (2001), Panavelil (2011), and Savvidou (2004), and to note few more like Khatib (2011), and Marin (2017) refer to this fashionable way of teaching as the 'integrated approach'. A model as such is a very active and sound teaching paradigm that cements the ideal matrimony between 'the intrinsic' and 'the extrinsic' value of the poetic texts treating each element as complementary to the other.

Absorbed by all those favourable conjectures, it is crucial to conclude that the integrated model is an advised model to teaching poetry, which is worthy of trying in a real learning environment. However, despite the persistent pedagogical views for following more fashionable active ways of teaching, change for betterment is still up in the air. Admittedly, many of the research recommendations become a dry ink on forgotten papers as most of the brilliant ideas are not followed genuinely, while some other instructions rarely appear on the ground of practice. In this spirit, today, poetry needs to be revisited for more persuading, resounding, and well-designated educational purposes. In this paper, it is suggested that poetry could be fully exploited for strengthening EFL learners' MC. The nudge towards this objective orientation stems from the fact that only a few inquiries have focalised on the area of metaphor vis-à-vis poetry learning. Adding to that, what is thoroughly missing today in ELT education concerning the study of poetry is how to stimulate metaphor teaching through the poetic metaphor itself using a strategic model of instruction. At this juncture, the current study raises the challenge of searching the missing puzzles that fit neatly into the jigsaw of metaphor teaching by examining the possibility of applying the integrated approach as a way to develop the EFL student' MC in poetry classes. Ferreting out solutions to the previously illuminated practical issues will give us insightful answers to the oftraised question, what poetry teaching can contribute to the study of the language?

\section{Research Methodology and Design}

In an impulse to give a thorough appraisal to the topic under the lenses of investigation, the researcher has pertinently undertaken his research paper through the use of descriptive/diagnostic

Arab World English Journal for Translation \& Literary Studies 
research study, which is geared by the use of a Case Study method in gathering data. Undoubtedly, Case Studies are potential methods of inquiry, and this could be due to several factors. Doubtlessly, this investigative method is a very salient academic type of research, for its ability to enrich the repository of data stored, allow the investigator to describe his need situation, diagnose persisting symptoms, and deepen one's perception of a particular topic under study. In that, Duff (2012) notes:

The greatest strength of case study is its ability to exemplify larger processes or situations in a very accessible, concrete, immediate, and personal manner.[...] Case study research seeks depth rather than breadth in its scope and analysis. Its goal is not to universalize but to particularize and then yield insights of potentially wider relevance and theoretical significance. (p. 96)

For a more clarified depiction of the case study in this paper of research, the following rubric will provide a living picture of the qualities typical for the target group taking part in this study.

\section{Target Group (Case Study)}

The researcher has opted for his participants among the first year EFL students at the University of Tlemcen (Algeria), as they are fresh learners of English whose age ranges from eighteen to twenty-one years old. The choice of this grade is ascribable to the fact that many scholars, viz. (Cameron, Candlin, \& Sarangi, 2003; Piquer Píriz, 2011) among others, have strongly recommended the importance of using metaphor in education from an early stage of the learning process. These metaphor-based classes designed for the novice learners might be a stout stimulus for promoting their metaphoric awareness (Low, 1988), extending their vocabulary repertoire (Boers \& Lindstromberg, 2008), and developing their language proficiency in general. In respect to this, the target group is composed of 40 students (twenty-one female and eleven male), that the researcher has selected randomly from among two literature classrooms studying along the academic year 2018/2019. Those students have accepted willingly to act as guinea pigs for the experiment designed for the accomplishment of this study (Pre/Post Test).

\section{Description of the Instruments}

To pursue the target aspiration for testing the validity of the hypotheses stated little ahead in this paper, the investigator has embarked on before-and-after study design or what is widely known as Pre/Post Testing. The use of this quantitative tool of research is invaluable by virtue of its ability to appraise the quantifiable "change in a phenomenon or to assess the impact of an intervention" (Kumar, 2010, p. 109). Its vitality in this context lies in evaluating the EFL learners' skills and outcomes before and after learning poetry through an integrated approach that represents the intervention in this study. However, in the hope to minimize, or to relinquish, the side effect that could occur when we deal with two samples that might have varied learning styles and unbalanced potentials, the inquirer has favoured opting for One-Group Pretest-Posttest Design. This analytical strategy stipulates working with only one sample that acts both as a treatment and a control group at the same time. The experiment used in this research includes identical activities that follow Gibbs' (1992, 1994) model of metaphor processing (comprehension and recognition, interpretation, and appreciation), already illuminated in this paper. By going through these stages,

Arab World English Journal for Translation \& Literary Studies 
the study will examine the ability of the students to cope with crucial components of MC, namely the ability to draw a distinction between metaphor and non-metaphors, interpret metaphors fluently, produce creative metaphors, and appreciate metaphors in poetry. Before fleshing out the procedures and the experiment criteria, it is worthy of highlighting the poems we have worked on in the test. In this process, the study has deliberately incorporated four poems as testing materials, viz. Anne Bradstreet's "To My Dear and Loving Husband," "Daffodils" by William Wordsworth, "The Glory of the Day was in Her Face" by James Weldon Johnson, and "A Red, Red Rose" by Robert Frost (see Appendix A). The rationale behind this selection is that most of these literary pieces can strike a chord with the novice L2 students, who are very likely to appreciate their neat style and conventional themes that look very congenial to their needs and desires.

\section{Procedures in the Pretest}

Given that familiarity with the teaching materials involved in the experiment is a necessary process, the teacher (the experimenter in this study) has devoted a course for each piece of poem. The presentation of the lecture takes place at the outset of the second semester, which marks the end of 'prose-oriented syllabus,' and the beginning of a new literary genre, which is poetry. In this context, the investigator has undertaken a language-based model as a teaching method using some close reading strategies (like reading aloud and text marking), which centre basically on the stylistic aspects of the text, including (rhyme, rhythm, sound pattern, figurative language, and meaning).

The first test of the experiment consists of 06 exercises that the participants have to accomplish in an allotted time of $2 \mathrm{~h}$. These activities fell mainly under three rubrics that go with the same line of Gibbs' figurative language processing; each rubric includes two exercises (see Appendix B). In the first activity, the learners are encouraged to distinguish between 10 expressions extracted from the poems under examination, by stating whether they are literal or figurative. However, the second exercise invites the participants to categorize 05 metaphorical images shaped under different conceptual domains. At the beginning of the second rubric, the students have had to interpret (05) figures of speech by paraphrasing them in the style of prose, whereas, in the second exercise, participants have to create (05) metaphors beginning with words used by the poets. Finally, the last section in the pretest offers the learners more latitude to evaluate (05) selected metaphors in terms of richness, compatibility, the worthiness of reading, creativity, imagination, and emotive effect (illustration is compulsory). Finally, the closing exercise invites the learners to explain whether the use of some metaphors relevant to the theme of 'love' in the poems has added any strength, genuineness, novelty, artistic beauty, or elicitation to the values and intentions conveyed by each writer.

\section{Procedures in the Posttest}

Before immersing the students in the last test, the experimenter had assigned the participants to reattend extra sessions devoted to analyzing the same poems. However, at this time, he puts more emphasis on the cultural context of the verses and the reader's response to the text. As a reminder, these aspects of literary exploration are the very characteristics of the integrated approach, which 
incorporates different levels of analysis; linguistic, cultural and aesthetic. In this process, the teacher has embarked upon the following criteria of study in the classroom:

- To offer the learners a lot of insights about the background of the poet (biography, trend, attitudes, and culture, etc.)

- The students read the poetic texts intensively, and in deep contemplation. The aim is to urge them to discover the variant dimensions of meaning; connotative, emotive, and social implications embedded in teaching materials

- Stirring students-students interaction in the classroom; as an active teaching strategy that allows the verbal exchange of assumptions and thoughts in the classroom

- The teacher invites the learners to re-contemplate over the lesson materials in an audible way, by raising critical issues, and sensitive questions that help them reframe their attitudes, and change their feelings towards the moving verses of the poem

- The researcher explains some cultural features, connotations, and cross-cultural differences between the texts

- Last but not least, the participants have to judge the richness, authenticity, and the critical values of the poems that they have explored in the classroom

After assisting the learners in an extra four lectures, the posttest is piloted and distributed to the same group of participants. The attempt is to assess their progress after the use of the treatment. As a matter of fact, the posttest and the pretest look quite identical concerning the testing materials, the allotment of time, and the number of rubrics and activities. Yet, the types and the items of questions involved in each testing part are somehow different. Meaning, the first section in the posttest based on metaphor comprehension incorporates two exercises. The first one invites the examinees to extract two figures of speech from each poem, and to identify their type, whereas, the second is an activity that contains 12 'true-false' questions, in which the students have to state if some expressions are literal or metaphoric (see Appendix C). Interestingly enough, the second rubric accentuates the second stage of metaphor processing (interpretation). The first exercise consists of (08) multiple-choices questions, which call the participants to tick the typical metaphor interpretation from among three options; one signifies the correct elaboration of the utterance, while the two other phrases present misleading answers. Both of the two other choices are tricky in the sense one gives a literal interpretation (word-for-word interpretation), while the other one embodies a nonsensical sentence, which is grammatically correct, yet semantically deviant (semantic deviation).

In the same vein, the second activity asks the examinees to translate some metaphoric images into the standard Arabic that is their native language. The challenge in this context is checking the learners' ability to transfer metaphor cognition from L2 to L1, by eschewing the use of a word-byword interpretation. Besides, this activity is another effective assessment strategy that helps to consider the learners' development of metaphor interpretation competence by evaluating their potential to rephrase their understanding the figures of speech in poetry using their L1 instead of the (TL) (Boers \& Lindstromberg, 2008). Finally, the last rubric also entails two exercises. The first task encourages the students to take more risks by generating some conceptual mappings from some complex metaphoric images that are, implicitly or explicitly, applied in the poem "I 
Wandered Lonely as a Cloud." The students are assisted by some source domains beginning with '(DANCE IS ), (EYE IS ), (COMPANY IS ), which they have to complete by revisiting the semantics of metaphors used by Wordsworth. The second step is to demonstrate whether the metaphoric images created by the poet ought to provoke their sense of appreciation of the poem. In the closing exercise, the learners have to write a short composite to compare the metaphoric images used by all of James Weldon Johnson, Robert Burns, and William Shakespeare. The purpose behind is to show the impact of the creative poetic images on stirring the literary appreciation of the poems, not least the significance of the metaphor in illuminating each poet's understanding of love. After delineating the main procedures of the experiment, the section which follows will display the most substantial results of the tests, which will help the inquirer to shape insightful interpretations and constructive conclusions.

\section{Analyses and Interpretations}

\section{Pretest Results}

During the evaluation process, the teacher has devoted 20 points for each rubric, which makes a total of 60 points altogether. After thorough appraisals of 40 test sheets, the descriptive statistics of the final grades calculated through SPSS reveal the low performance of the participants in the first trial (see table one). The table portrays that the majority of the gained scored fluctuate below the average with a total mean of 24.43 (the lower and the lower score are 9.5, and 34.5 respectively). Guided by the same statistics, one may notice that the participants' scores revolve around the median 25 , while the mode is 28 . Besides, the measures of variability have also demonstrated that the dispersion between the variables of the pretest is thoroughly high (std. deviation $=6.92$ ). Leaning on the fact that most scores are mostly far from the centre permitting a slight cleavage between the highest and the lowest score may allude that the results are not very coherent, and thus, not that satisfactory. Impressionistically, the findings of the pretest do not reflect satisfactory outcomes at all.

Table 1. The descriptive statistics of the pretest score

\begin{tabular}{lllll}
\hline & Comprehension & Interpretation & Evaluation & Pretest \\
\hline $\mathrm{N} \quad$ Valid & 40 & 40 & 40 & 40 \\
$\quad$ Missing & 0 & 0 & 0 & 0 \\
Mean & 9,250 & 8,350 & 6,838 & 24,438 \\
Median & 10,000 & 9,000 & 7,000 & 25,250 \\
Mode & 11,0 & $9,0^{\mathrm{a}}$ & 4,0 & $28,0^{\mathrm{a}}$ \\
Std. Deviation & 2,8420 & 2,5120 & 2,7882 & 6,9200 \\
Variance & 8,077 & 6,310 & 7,774 & 47,887 \\
\hline
\end{tabular}

Arab World English Journal for Translation \& Literary Studies 


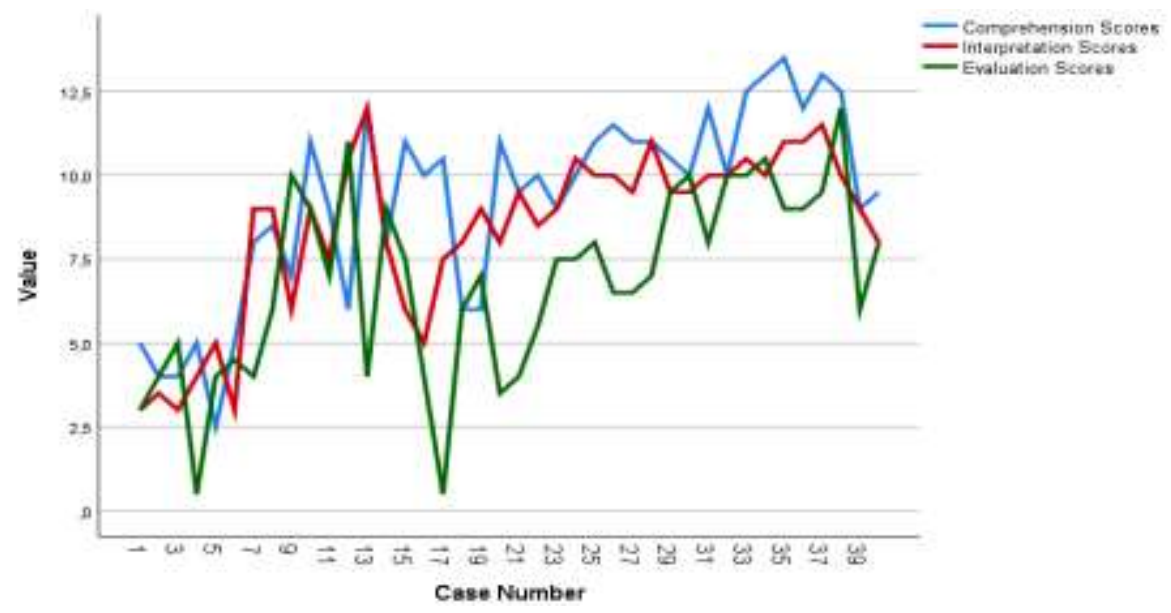

Figure 1. Line-chart of the descriptive statistics of the pretest score

For a more particularized glimpse into the students' performance in each metaphoric understanding processing (see figure one), the data show that the mean on comprehension (9.25) is the highest compared to interpretation (8.53), and evaluation (6.83). Saliently, the target group did remarkably better in the first two exercises included in rubric 1 (assessing comprehension). However, though the grades are not a success across the board, $(35 \%)$ of the participants could achieve pleasing scores ranging from 10 to 13.5. Importantly, the findings disclose that (95\%) of the right answers are accumulated from the first exercise that seems much easier than the second. As far as metaphoric comprehension is concerned, most students could not provide the right conceptual domains overlapping the metaphors used by the poets, like since she is gone, and my heart with pleasure fills, which may be derived respectively from the conceptual mapping DEATH IS LEAVING, and HEART IS A CONTAINER. However, the scores in the second rubric (interpretation) seem less satisfactory compared to the first one (Mean 8.35), or not satisfactory altogether (as contributing only in $24.2 \%$ of the total mean). The majority of the examinees could not come with coherent and cohesive literal paraphrasing to some figurative images, like while the sands of life shall run, or my love is such that rivers cannot quench, which they could not approach its meaning using their proper words.

Unlike interpretation, the results on evaluation were even more pathetic than the researcher had expected. The evaluation of metaphor is noticeably the most daunting processing that instigates many perils for the participants. Many students could hardly construct critical literary judgements that could best illustrate the multidimensional impacts of the metaphoric images on the general perception of the poetic texts. As displayed above, 92.5\% of the participants' scores range from (2-10pts), most of which have been gained from the second exercise that is itself at a low ebb. However, the first task is catastrophic because many participants have favoured not to answer the questions leaving the gaps blank. Strikingly along the process of evaluation, the examiner has observed that, in the last task, even the minority (12.5\% of the participants) have chosen some metaphors from the first stanza of each poem (e.g., I wandered lonely as a cloud, and O my Luve's 
like a red, red rose). Then afterwards, they have ticked some items of evaluation randomly providing no tangible explanations at all.

Overall, the grades on the pretest show a moderate ability on the part of the learners to differentiate between literal and non-literal images imbedded in classical English poetry. Worse still, the participants' capacity to interpret as well as to evaluate those images has gone badly off the rail, as most of them have failed to provide acceptable answers to many questions of the test. To these ends, it is necessary to gauge the posttest results set at the end of the year. This step would allow the researcher to measure any improvement or regression in the students' achievements after attending extra poetry classes orchestrated by an integrated teaching model.

\section{Posttest Results}

From the prism of the second trial assessments, the scores (60pts) -that are distributed relatively in each rubric -have yielded noteworthy results. As displayed in table two, the students' scores that range from 15 to 47 out of 60 - rise slightly above the average with a mean of 32.86 . More involving, this test reveals that 30 participants - representing $75 \%$ of the examinees -have managed reach the mean average. In a quest for a more penetrating look into the measures of central tendency, the value of the median, as indicated below, reveals that most of the students have got satisfactory marks that orbit around 33.25, while the score distribution occupies mode 33 . These statistics signify a significant landmark of improvement in the students' performance after treatment. With the same regard, while examining how spreads out the rating of scores are, the average of Standard Deviation as represented in table two (Std. Deviation=7.88) indicates that the grades after intervention do not disperse a lot from the mean, which reflects a favourable inference.

Table 2. The descriptive statistics of the posttest score

\begin{tabular}{lllll}
\hline & Comprehension & Interpretation & Evaluation & Posttest \\
\hline $\mathrm{N} \quad$ Valid & 40 & 40 & 40 & 40 \\
$\quad$ Missing & 0 & 0 & 0 & 0 \\
Mean & 11,125 & 10,863 & 10,875 & 32,8625 \\
Median & 11,250 & 10,500 & 11,000 & 33,2500 \\
Mode & $12,0^{\mathrm{a}}$ & 10,0 & $11,0^{\mathrm{a}}$ & $33,00^{\mathrm{a}}$ \\
Std. Deviation & 3,2339 & 2,5820 & 2,8504 & 7,88864 \\
Variance & 10,458 & 6,667 & 8,125 & 62,231 \\
\hline
\end{tabular}

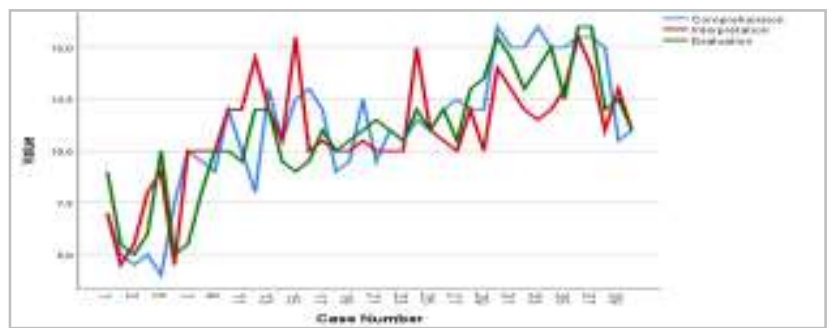

Figure 2. Line-chart of the descriptive statistics of the posttest score

Arab World English Journal for Translation \& Literary Studies 
With a wish to sifting every scrap of evidence, table two also enlightens substantial data concerning the shift in the mean in the threefold processing of MC. As can be noticed, the outputs show considerable improvement in the results in all stages. As for comprehension, the mean $(M=11.12)$ reached by the participants in the posttest drops the veil on the dramatic progress achieved after the experiment (see also figure two). Most examinees have grown more able to mark a clear cut between poetic metaphors and non-metaphors ingrained in the test. Concerning the assessment of interpretation, six students $(15 \%)$ only could not reach the average, while the rest of them (85\%) have succeeded in gaining good scores ranging from 10 to 15.5. These results that culminate into a mean (10.86) show the remarkable development in the students' capability to delve into complexmeaning utterances in poetry. What is also spectacularly significant in these findings is that fifty per cent $(50 \%)$ of the participants have enhanced their ability - to a certain extent - to cope with witty and creative images in English poetry using their first language (L1). For instance, Robert Burns' beautifully weaved mixed-metaphor 'O my Luve's like the melodie/that's sweetly played in tune, 'has been dexterously translated by the majority of the students into meaningful Arabic metaphors. One of those well-elaborated examples is /hobı lækəh Ju:Jbihひ æ’edæbə ə’lha:n

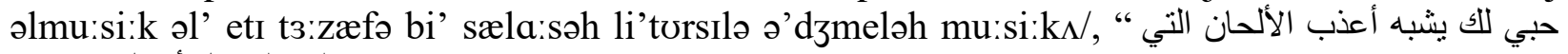
تعزف بسلالسة لترسل أجمل موسيقى," which says pretty the same of the original metaphor, but it shows more creativeness in expressing meaning in Arabic.

As far as evaluation is concerned, the stride on grades in this process has been unexpectedly phenomenal. What lends colours to this evidence are the measures of central tendency highlighted on the table above (mean=10.87, Median=11, Maximum=16) that reflect a conspicuous enhancement in the students' metaphoric evaluation skills after treatment. Importantly, the majority of the students have done better in the last exercises compared to the first trial. Most of them could find many conceptual metaphors which William Wordsworth implies in his "Daffodils," like EYE IS MEMORY and COMPANY IS CROWD. As for the first example, the thorough in-class exploration over the various cognitive (denotative), and social meanings associated with the word 'eye,' explained in the classroom, has sustained the learners a great deal in the process of evaluation. By shadowing some overused connotations to the term eye, like be all eyes (indicating CARE or INTEREST), have an eye on, or in sb's eyes (indicating THINKING), the learners could realize that sometimes the eye signifies things that transcend beyond the act of seeing, as to raise one's sub-consciousness, and to call something into memory. At this stage, the researcher has proceeded with $t$-tests to appraise the possible treatment effect on the learners' outcomes.

\section{Comparison between the Pretest and the Posttest Scores}

In this process, the findings of the pre-test have been measured up against the posttest through the conduction of two $t$-tests using (SPSS):

A non-parametric test-One-sample Kolmogorov-Smirnov Test: it aims to test the normality of variables. To confirm the normal distribution of scores, the value of significance (sig) defined by the symbol (P) must be higher than the alpha significance level 0.005 or $5 \%$.

Arab World English Journal for Translation \& Literary Studies 
Parametric test-the Paired-Samples t-Test: it tests whether the change in the same participants' scores after a course of instruction is statistically significant. The test includes the measurement of the probability of significance value (P-value), the degree of the difference between the variations of the test (T-value), the degree of freedom of variables (df), and the correlation between tests (rp).

Succinctly, the results illuminated on table three and four ensure the factor of normality demonstrated by the value of significance that is noticeably bigger than 0.005; (KolmogorovSmirnov, Pre-test ' $\mathrm{P}=0.17$ ', Post-test ' $\mathrm{P}=0.20$ '/ Shapiro-Wilk, Pre-test ' $\mathrm{P}=0.010$ ', Post-test ' $\mathrm{P}=$ 0.13 '). To have a concrete outlook on those results, the normal probability plots, displayed in figure three and four, show that all the pretest and posttest marks follow, or approximate to the line of normality.

Table 3. Kolmogorov-Smirnov normality test (K-S test) of the pretest score

\begin{tabular}{lcccccc}
\hline & \multicolumn{3}{c}{ Kolmogorov-Smirnov $^{\text {a }}$} & \multicolumn{3}{c}{ Shapiro-Wilk } \\
& Statistic & df & Sig. & Statistic & df & Sig. \\
\hline Comprehension &, 154 & 40 &, 018 &, 932 & 40 &, 019 \\
Interpretation &, 202 & 40 &, 000 &, 884 & 40 &, 001 \\
Evaluation &, 106 & 40 &, $200^{*}$ &, 966 & 40 &, 276 \\
Pre-test Scores &, 118 & 40 &, 173 &, 923 & 40 &, 010 \\
\hline
\end{tabular}

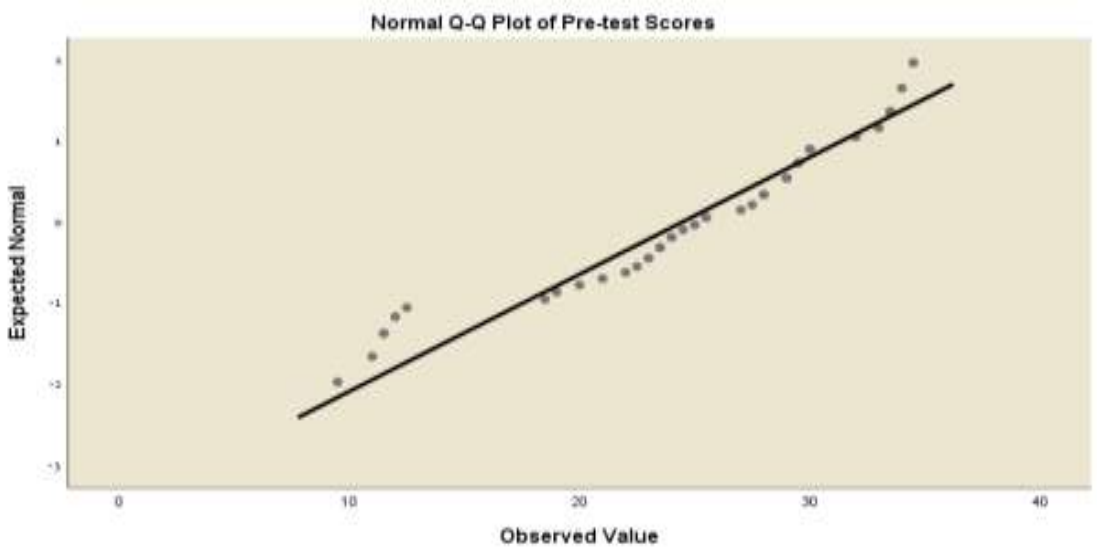

Figure 2: Normal Q-Q plot of the pretest scores

Table 4. Kolmogorov-Smirnov normality test (K-S test) of the posttest score

\begin{tabular}{lccccccr}
\hline & \multicolumn{3}{c}{ Kolmogorov-Smirnov $^{\text {a }}$} & \multicolumn{4}{c}{ Shapiro-Wilk } \\
& Statistic & df & \multicolumn{2}{c}{ Sig. } & Statistic & df & \multicolumn{1}{c}{ Sig. } \\
\hline Comprehension &, 110 & 40 &, $200^{*}$ &, 948 & 40 &, 066 \\
Interpretation &, 219 & 40 &, 000 &, 929 & 40 &, 015 \\
Evaluation &, 115 & 40 &, $200^{*}$ &, 953 & 40 &, 100 \\
Posttest scores &, 112 & 40 &, $200^{*}$ &, 957 & 40 &, 136 \\
\hline
\end{tabular}

Arab World English Journal for Translation \& Literary Studies 


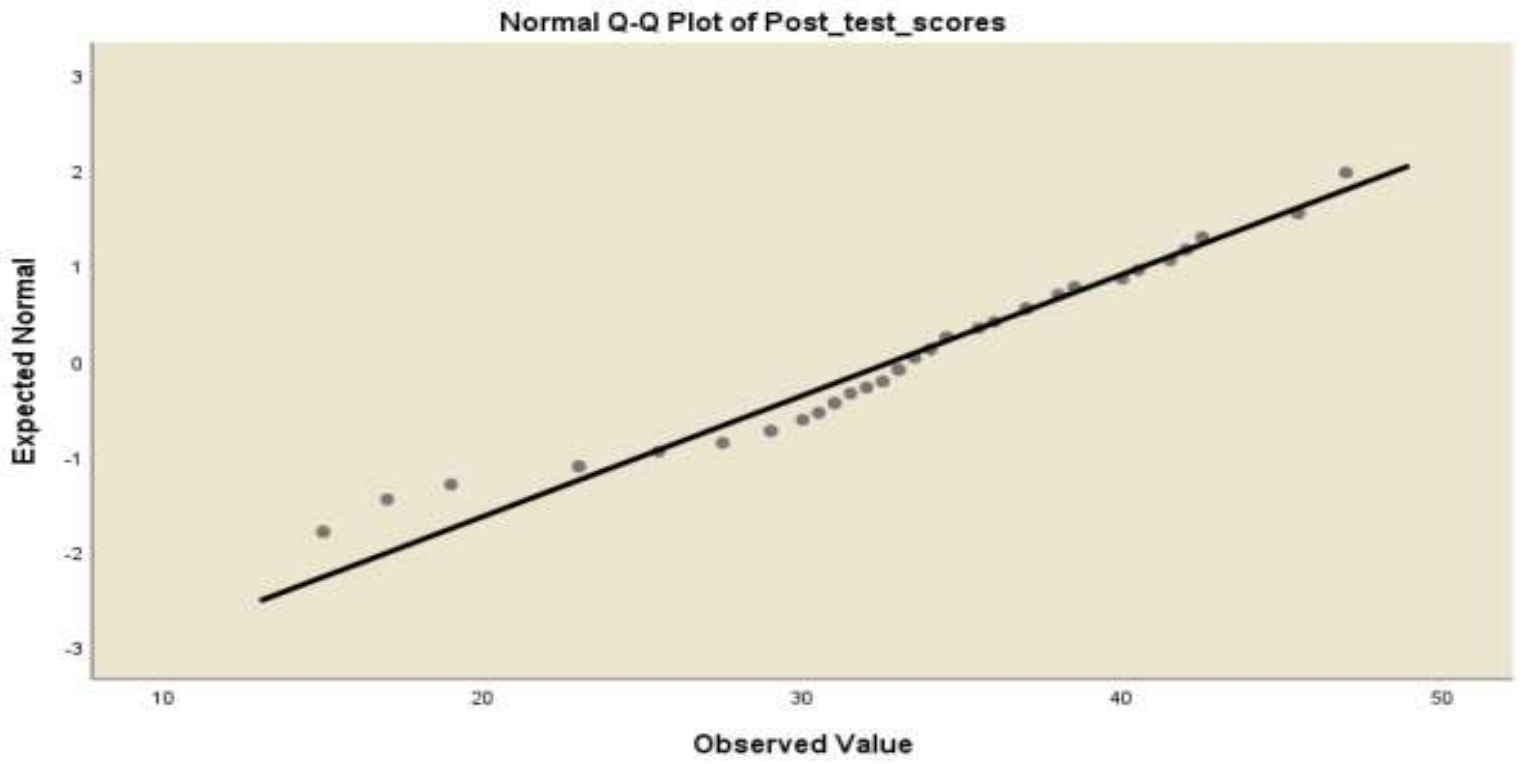

Figure 3: Normal Q-Q plot of the posttest scores

With a reassuring certainty that the distribution of the scores complies with the rules of normality, the researcher has conducted a Paired-Samples t-Test to check treatment significance. As the findings suggest (see table five), the participants attending extra sessions on poetry via the implementation of the integrated framework prove to hone their metaphoric competence at the end of the second semester (Mean=32.86, $\mathrm{SD}=7.88$ ), compared to the beginning (Mean=24.43, $\mathrm{SD}=6.92$ ), with a difference in mean of -8.43 . As noticed in the second box, the grades of the students setting for both tests are highly associated, if one considers the strong correlation coefficient exhibited in the output ( $\mathrm{rp}=0.898)$. As a reminder, the correlation is always between the scale values 0 and 1 ; the closer values are to 1 ; the stronger is the relationship between the two variables. Thus, the groundbreaking inference that one might draw upon is that the outcomes of the participants in the posttest raise in sympathy with the grades earned on the first test (pretest) because the correlation coefficient comes closer to the value 1.

One last crucial point to draw out from these findings is that the difference between the pretest and the posttest scoring proves to be statistically (highly) significant (see also figure five). The output spelt out in the closing box; $\left(\mathrm{p}=0.000<0.001, \mathrm{t}=-15.36, \mathrm{df}=39^{\prime}\right)$, reveals first that the $\mathrm{p}$ value is smaller than 1 , and therefore, one can make the substation that the use of the experiment has been a success. Another efficient adjunct to the reliability of the integrated model is the t-value 
AWEJ for Translation \& Literary Studies Volume, 4 Number 2 May 2020

Resurrecting 'Metaphor' inside the EFL Poetry Classroom

Bouali

characterized by a high magnitude far-bigger than $-0(t=-15.36)$ with a significant degree of freedom 39.

Table 5. SPSS-paired samples t-test of difference in the pre/posttest scores

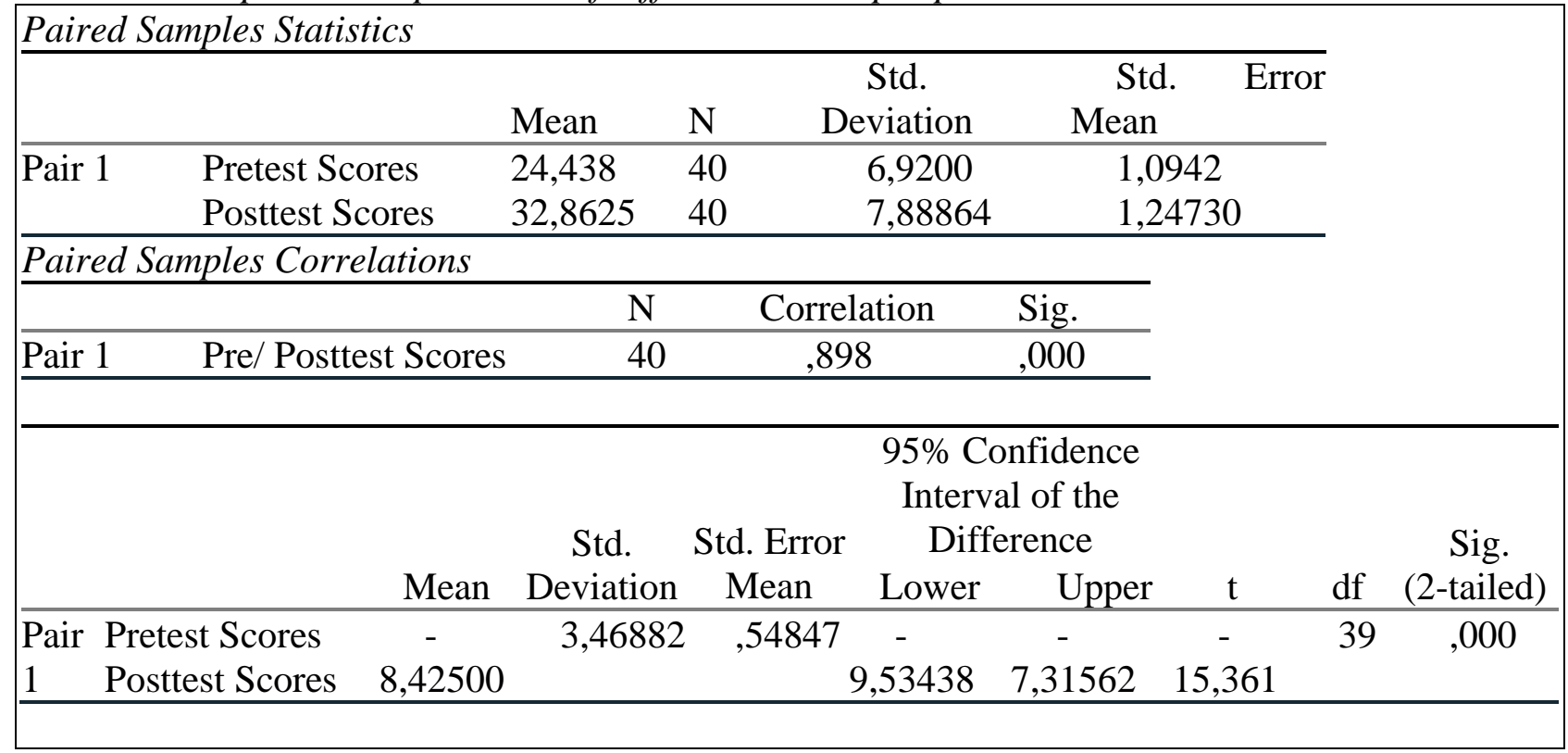

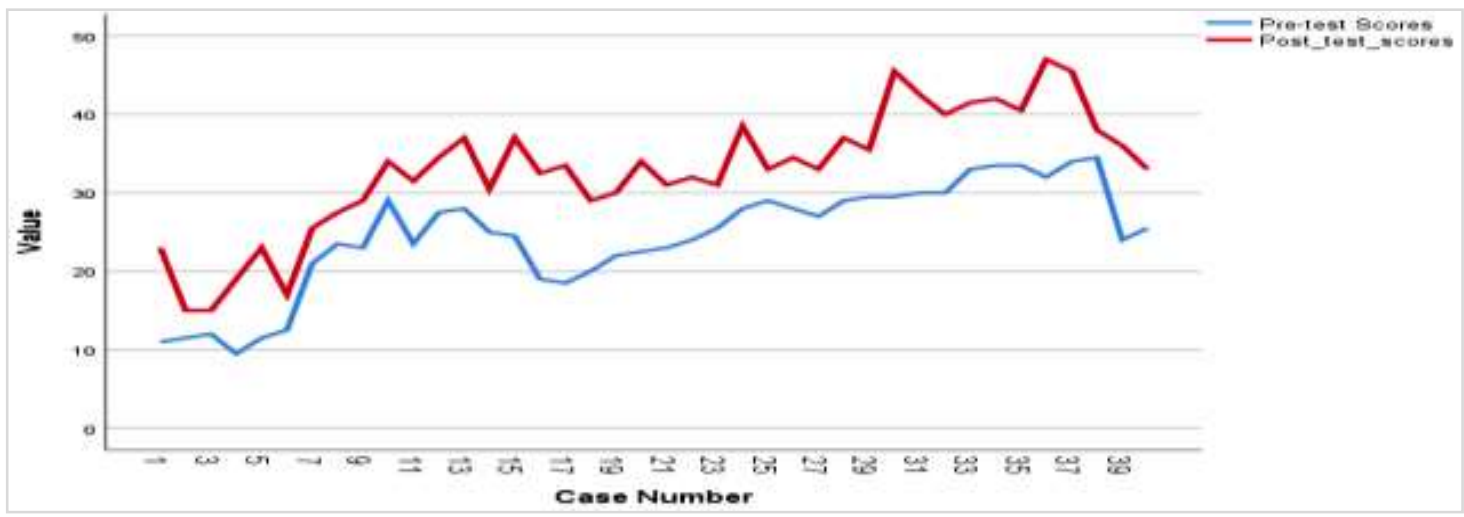

Figure 5: Line-chart of the difference of the pre/posttest scores

Fortified by these findings, one may conclude that the novice Algerian EFL students, who have been attending poetry classes through the use of an integrated approach, have developed their $\mathrm{MC}$ at the end of the semester compared to the beginning. This conclusion testifies to the validity of the hypothesis drawn at the outset of this study, which upholds the belief in the potential of the integrated approach to developing the learners' figurative language awareness and metaphorical thinking in poetry classrooms

Arab World English Journal for Translation \& Literary Studies 


\section{Summary of the findings}

For getting from the world of hypothesising into the world of the ascertainable truth, it is enormously significant to put all the results in one basket for the attempt to test the credibility of the research hypotheses. Retrospectively, the researcher has presumed at the outset of this study that the integrated model to teaching poetry could personify a sinew for promoting the lower-level undergraduate' MC at the University of Tlemcen (Algeria). By drawing on the main results displayed painstakingly in this study, one could reach to the conclusive proof signifying the validity of the previously underlined contention. In other words, though limitations are indispensable, teaching poetry through the integrated approach has influenced the outcome of the learners to a considerable extent, since the majority among them could outperform their weak results in the pretest. The impact has just been worthwhile, and obviously, significant in each metaphoric understanding processing.

As illuminated so far in the analysis of the tests, the integrated model urges the participants to sink profoundly into the bottom of the poem. The intensive language-based teaching strategies (e.g., text marking, reading aloud, close analysis) that have been fruitful for laying bare the ambiguities besieging the poetic style. Therefore, this preliminary teaching strategy contributes to furnishing the learners' mind with conceptual reasoning skills that help them grow somehow into meaning-sensitive readers. As for metaphoric interpretation, the personal growth strategies adding to the exploration of the cultural perspectives implied by the poets seem to offer the learners a chance to spread their wings, and to start thinking out of the box. As visibly noticed, the students could make a remarkable improvement regarding the ability to elaborate on the meaning of many metaphors in poetry. Along the same lines of argumentation, the study would also disclose the ability of the integrated model to embolden the evaluative potentials of the learners to discuss the role of metaphor in its context. As could be generalised from the present study, the active tasks promoted by the researcher (in-class interaction, intense reading, creative writings, among others), could be the stimulus for encouraging the learners to see the images used by the poets replete with meaningfulness, vibrancy, and emotive effects. In a nutshell, this study manifests the effectiveness of the integrative teaching strategies in developing the learners' $\mathrm{MC}$.

From another empirical end, the study underlines the credibility of the second subsidiary hypothesis. As a reminder, the research avers that the learners will probably endure persisting difficulties along the process of metaphor analysis. For settling evidence against expectations, the assessment of the learners' outcome in each test portrays that the learners suffer from a severe deficiency almost related to written expression and L2 proficiency. Insistently, these weaknesses are not directly relevant to $\mathrm{MC}$ as much as to language use and usage. Those flaws put the teachers at the full alert of the necessity to employ more efficient teaching techniques that ought to help the learners defeat the barriers of the English language above everything else. By the end, to make the findings concord with the chief problematic of this study, it is worthy to note that rethinking poetic metaphors inside the Algerian EFL initial-grade classroom is both a pedagogical requisite and a might. Admittedly, re-stressing the area of metaphorical thinking is a step towards strengthening the cognitive potentials of the learners. Better still, conceptual metaphors personify

Arab World English Journal for Translation \& Literary Studies 
a focal point in metaphor teaching, which would awaken the learners to the significance of metaphoric reasoning, not just in literature, but also as a high-level activity of mind interwoven with peoples' use of the language and the way they think.

In this context, the mapping of a constructive teaching model to teaching poetry in the EFL classrooms that targets at enhancing the learners' MC encapsulate the genuine sense of this research. The prior significance resides in bringing the subject of metaphor back to life in such a fashionable way that offers an additional rigour to the concept of metaphor inside the Algerian learning spaces. In this spirit, the study thereby may contribute to opening the Algerian academics' eyes widely awake to the significance of metaphor in English teaching and learning. From another very noticeable pro side, and as related to the paramount objective of this research, the teachers would find the suggested integrated approach a very consistent, and a worthy-to-use method for enhancing the students' metaphoric thinking skills inside the classroom. Adding to those virtues, this research remains an exciting, curious space for those interested in cognitive linguistics and L2 teaching. However, despite the improvements witnessed in the learners' MC after the intervention takes place, apparently, the students still face a lot of handicaps relevant to syntax, semantics, and the deep engagement with the intricate poetic style. Absorbed by this reality, the teachers coming across this research may feel the necessity to double their synergetic efforts for promoting the learners' L2 proficiency above all. It is very enlightening to see through the prism of this paper that the learners are in an intense thirst to a lot of language practice. They are in a great need to grow the passion for reading literature, and equally appealing, to develop the yearning for travelling beyond the surface level of words where every bit invites a multiplicity of ways for speculation. By the close of this humble paper, it is crucial to assert that any academic research starts in wonder and ends in wonder. The final wonder that anchors in the curious inquirer's mind will prevail upon him to think critically of a wider breadth to this research. Correspondingly, one can go further than this limited study, and thus, could think deliberately of the possible ways to engage the learners with metaphor through the use of technology and media studies. On the other way round, this research can be enriched by examining the effect of using metaphors to develop other areas of competence inside the EFL classrooms, like cross-cultural competence and conceptual fluency.

\section{Conclusion}

This study marches into our point of departure, but more reassuringly, this time it makes us rebelieve in poetry as a magnetizing subject of education, and therefore, it could be put at the same magnitude like anything else. If the classroom is taught through a physician theory, probing every corner of the text purposefully, deeply, and not in a hurry, poems may grow into a permanent mightily instructive resource in the classroom. As revealed in this research, one of the benefits of teaching poetry through a synthetic model is to engage the learners emotionally, physically, and cognitively with metaphors. Substantially, the test shows that the use of an integrated model has enhanced -to a considerable extent - MC of the Algerian EFL students at Tlemcen University. What confirms first the efficacy of this teaching model is the thriving progress noticed on the students' achievements after being involved in some integrated-based techniques of learning. In a more particularized fashion, working through different levels of integration; (methodology level,

Arab World English Journal for Translation \& Literary Studies 
techniques level, skills level, and efforts level) in the analysis of poetry has in a way maximized the learners' potential to discriminate between the literal and the figurative uses of the language (metaphor identification). It could also sensitize them to find the chemistry between the language and the poetic materials. Participants could also interpret a vast range of CMs which featured robustly in different English poems, and this could be ascribed to the ability of the integrated approach to reframe the students' thinking habits of minds and to deepen their understanding of the TL. Better still, stimulating personal growth activities in poetry classroom (interaction, talk-itout, creative writing, and role-playing) have captured the attention of those who have their heads in the clouds to the lure of metaphors in poetry. Many students could triumph upon themselves by judging the aesthetic, emotive and the cognitive effect of love ' $\mathrm{CMs}$ ' in the language, and their invaluable role in constructing the general meaning of the poetic pieces of art. Notwithstanding, coping with creative poetic metaphors for undergraduate learners has not been a piece of cake. Despite improvements, many students could not grasp all the figures of speech distracted from the poems under examination. This pitfall is perhaps due to many difficulties with which the EFL learners are still putting on, namely the low language proficiency, and the exposure to literature.

In a nutshell, and despite the perils mentioned above, teaching metaphor stays one the picturesque journeys to the mysteries of the language. Therefore, restoring its core ability in the EFL literature curriculum can bring language into life, by reserving much of the beauty of the texts. Also, it could disclose the secrets that disguise under this beauty. As grounded in down-toearth evidence, we would also be reassured to recommend the integrated model as a powerful model of instruction. This hybrid method of teaching can free the language to get out of its stylistic shell, while it offers the learners latitude to see the text beyond the confines of the literal world, beyond time and space, as a signboard to reality. By the end, for the hope of promoting MC as a breath of fresh air in the EFL milieu, the research will first suggest that the teachers should target at developing the learners' metaphoric awareness-raising. To reach these ends, the students have to practice conceptual mapping through task-based activities (like, word-play, imagecreation, brainstorming, and filling gaps) that focus on CMs (e.g., LIFE IS A JOURNEY, ARGUMENT IS FIRE). However, to develop more intimacy with the TL, the teacher has to stir the learners' passion for reading literary works as much as possible. They should also practice the language by doing role-play activities, problem-solving tasks, and multiple-choice activities). Further, the teachers can use advanced supportive visual aids (e.g., slide-share, videos, powerpoint presentations, drawing and moving pictures). Amusingly, with visual aids, understanding the symbolic images will be trivialized through flesh and blood personification of abstract thoughts, as only few can resist the lure of colours, music, bright-light, and mutable pictures that pirouette across the screen. The wand of computer can somehow levitate the magic of words, magnetize some fond eyes of acoustic-visual learners, and fill what is missing in the literature classroom. All in all, the revival of metaphor in education may develop human resources, open new gates of understanding, entertain, and help the learners and the teachers raise the bare, to a limitless horizon.

\section{About the author}

Amina Bouali is an assistant teacher of literature and a former instructor for global virtual classrooms (GVC) in UABT 2. She holds a Magister degree in the didactics of literary texts and

Arab World English Journal for Translation \& Literary Studies 
civilizations from UABT, Tlemcen (Algeria). She is also a would-be doctor in English literature, whose research investigates the potential of comparative literature in ELT education. Her fields of interests include EFL literary studies \& criticism, applied linguistics, comparative literature \& cultural studies, and distance learning. ORCid ID: https://orcid.org/0000-0003-0933-1802

\section{References}

Antika, R. (2016). Poetry in EFL Classroom. TELL-US JOURNAL, 2, (2), 20-35. https://doi.org/10.22202/tus.2016.v2i2.1335

Avis, P. (1999). God and the Creative Imagination: Metaphor, Symbol and Myth in Religion and Theology. London; New York: Routledge.

Aydinoglu, N. (2013). Integration of Poetry with Vocabulary Teaching. Mediterranean Journal of Educational Research, (14), 274-284.

Berrada, K., \& Jahfa, A. (Eds.). (2011). Metaphor and Cognition (Force Equipment.). Casablanca: Laboratory Publications.

Bilsky, M. (1952). I. A. Richards' Theory of Metaphor. Modern Philology, 50, (2), 130-137.

Bishop, W., \& Starkey, D. (2006). Keywords in Creative Writing. Logan: Utah State University Press.

Black, M. (1962). Models and Metaphors: Studies in Language and Philosophy. Cornell University Press.

Boers, F., \& Lindstromberg, S. (Eds.). (2008). Cognitive Linguistic Approaches to Teaching Vocabulary and Phraseology. Berlin: Walter de Gruyter.

Cameron, L. (1999). Identifying and Describing Metaphor in Spoken Discourse. In L. Cameron \& G. Low (Eds.), Researching and Applying Metaphor (pp. 105-132). Cambridge: Cambridge University Press.

Cameron, L., Candlin, C., \& Sarangi, S. (2003). Metaphor in Educational Discourse. London; New York: Continuum.

Cameron, L., \& Low, G. (Eds.). (1999). Researching and Applying Metaphor. Cambridge: Cambridge University Press.

Carter, R., \& Long, M. N. (1991). Teaching Literature. Harlow, Essex Longman; New York: Longman Pub.

Charteris-Black, J. (2004). Corpus Approaches to Critical Metaphor Analysis. Houndmills, Basingstoke, Hampshire ; New York: Palgrave Macmillan.

Cohen, L. J. (1993). The Semantics of Metaphor. In A. Ortony (Ed.), Metaphor and Thought (2nd edition., pp. 58-70). Cambridge England: Cambridge University Press.

Cortazzi, M., \& Jin, L. (1999). Bridges to Learning: Metaphors of Teaching, Learning and Language. In L. Cameron \& G. Low (Eds.), Researching and Applying Metaphor (pp. 149176). Cambridge: Cambridge University Press.

Crisp, P. (2003). Conceptual Metaphor and its Expressions. In J. Gavins \& G. Steen (Eds.), Cognitive Poetics in Practice (pp. 99-113). London: Routledge.

Deepa, P., \& Ilankumaran, M. (2018). Teaching Poetry Enhances Speaking Skills - an Analysis Based on Select Poems. International Journal of Engineering \& Technology, 7, (4.36), 619-623. https://doi.org/10.14419/ijet.v7i4.36.24211 
Dutta, S. K. (2001). Teaching Poetry in the School Classroom: An Integrated and Communicative Approach. CAUCE, Revista de Filologia y su Didactica, (24), 519-537.

Fauconnier, G., \& Turner, M. (2002). The Way We Think: Conceptual Blending and the Mind's Hidden Complexities. New York: Basic Books.

Garrett, J. (2007). Aristotle on Metaphor, Excerpts from Poetics and Rhetoric. Retrieved from http://people.wku.edu/jan.garrett/401s07/arismeta.htm

Gavins, J., \& Steen, G. (Eds.). (2003). Cognitive Poetics in Practice. London: Routledge.

Gentner, D., Holyoak, K. J., \& Kokinov, B. N. (Eds.). (2001). The Analogical Mind: Perspectives from Cognitive Science. Cambridge, Mass: A Bradford Book.

Gibbs, R. W. (1992). When is Metaphor? The Idea of Understanding in Theories of Metaphor. Poetics Today, 13, (4), 575-606. https://doi.org/10.2307/1773290

Gibbs, R. W. (1994). The Poetics of Mind: Figurative Thought, Language, and Understanding. Cambridge England: Cambridge University Press.

Gibbs, R. W. (2002). Identifying and Appreciating Poetic Metaphor. Journal of Literary Semantics, 31, (2), 101-112. https://doi.org/0341-7638/02/031- 101

Gibbs, R. W. (Ed.). (2008). The Cambridge Handbook of Metaphor and Thought. Cambridge: Cambridge University Press.

Gibbs, R. W., \& Steen, G. J. (Eds.). (1999). Metaphor in Cognitive Linguistics: Selected papers from the 5th International Cognitive Linguistics Conference, Amsterdam, 1997. Amsterdam ; Philadelphia: John Benjamins Publishing Company.

Green, T. F. (1993). Learning without Metaphor. In A. Ortony (Ed.), Metaphor and Thought (2nd ed., pp. 610-620). Cambridge; England: Cambridge University Press.

Grice, H. P. (1975). Logic and Conversation. In P. Cole \& J. L. Morgan (Eds.), Syntax and Semantics, Volume 3: Speech Acts (pp. 41-58). New York: Academic Pr.

Haley, M. C. (1988). The Semeiosis of Poetic Metaphor (Pierce Studies). Bloomington: Indiana University Press.

Hall, G. (2003). Poetry, Pleasure, and Second Language Learning Classrooms. Applied Linguistics, 24, (3), 395-399.https://doi.org/10.1093/applin/24.3.395

Holme, R. (2004). Mind, Metaphor and Language Teaching. Basingstoke, UK: Palgrave Macmillan.

Holyoak, K. J., \& Thagard, P. (1995). Mental Leaps: Analogy in Creative Thought. Cambridge, MA: MIT Press.

Hu, Z. (2010). On Hourglass Model of Poetry Teaching in College English Class in China. Journal of Language Teaching and Research, 1, (5), 636-639. https://doi.org/10.4304/jltr.1.5.636639

Hymes, D. H. (1972). On communicative competence. In J. B. Pride \& J. Holmes (Eds.), Sociolinguistics (pp. 269-293). UK: Penguin.

Katz, A. N., Cacciari, C., Gibbs, R. W., \& Turner, M. (1998). Figurative Language and Thought. New York: Oxford University Press.

Katz, J. (1981). Literal Meaning and Logical Theory. Journal of Philosophy, 78, (4), 203-233. https://doi.org/10.2307/2025504

Kellem, H. (2009). The Formeaning Response Approach: Poetry in the EFL Classroom. English Teaching Forum, 47, (4), 12-17. 
Khansir, A. A. (2012). Teaching Poetry in the ELT Classroom. International Review of Social Sciences and Humanities, 3, (1), 241-245.

Khatib, M. (2011). A New Approach to Teaching English Poetry to EFL Students. Journal of Language Teaching and Research, 2, (1), 164-169. https://doi.org/10.4304/jltr.2.1.164169

Kirby, J. T. (1997). Aristotle on Metaphor. The American Journal of Philology, 118, (4), 517-554.

Kumar, R. (2010). Research Methodology: A Step-by-Step Guide for Beginners. Los Angeles: SAGE Publications Ltd.

Lakoff, G., \& Johnson, M. (1980). Metaphors We Live By. Chicago: University of Chicago Press.

Lakoff, G., \& Johnson, M. (1999). Philosophy in the Flesh: The Embodied Mind \& its Challenge to Western Thought. New York: Basic Books.

Lakoff, G., \& Turner, M. (1989). More than Cool Reason: A Field Guide to Poetic Metaphor. Chicago: The University of Chicago Press.

Lazar, G. (1996). Using Figurative Language to Expand Students' Vocabulary. ELT Journal, 50, (1), 43-51. https://doi.org/10.1093/elt/50.1.43

Levinson, S. C. (1983). Pragmatics. Cambridge Cambridgeshire; New York: Cambridge University Press.

Littlemore, J. (2001). Metaphoric Competence: A Language Learning Strength of Students with a Holistic Cognitive Style? TESOL Quarterly, 35, (3), 459-491.

Littlemore, J., \& Low, G. D. (2006). Figurative Thinking and Foreign Language Learning. Basingstoke England; New York: Palgrave Macmillan.

Lossi, A. (2010). Metaphor. In H. R. Sepp \& L. Embree (Eds.), Handbook of Phenomenological Aesthetics (Springer Dordrecht Heidelberg., pp. 211-214). London \& New York: Springer Science \& Business Media.

Low, G. D. (1988). On Teaching Metaphor. Applied Linguistics, 9, (2), 125-147. https://doi.org/10.1093/applin/9.2.125

Mackey, A., \& Gass, S. M. (2005). Second Language Research: Methodology and Design. Mahwah: Routledge.

Maley, A., \& Duff, A. (1989). The Inward Ear: Poetry in the Language Classroom. Cambridge: Cambridge University Press.

Marin, M. (2017). An Integrated Approach to Teaching Poetry in a Greek EFL Classroom. A Case Study: Comparing Cavafy and Shakespeare. Research Papers in Language Teaching \& Learning, 8, (2), 89-102.

McKay, S. (1982). Literature in the ESL Classroom. TESOL Quarterly, 16, (4), 529-536. https://doi.org/10.2307/3586470

Melzer, E. B. (2001). Teaching Intercultural Communicative Competence through Literature. In M. Byram, A. Nichols, \& D. Stevens (Eds.), Developing Intercultural Competence in Practice. Great Britain: Cromwell Press Ltd.

O’Brien, T. (1999). A Suggested Model for Teaching Literature. Course Notes Presented at the Master Education, University of Manchester.

Ortony, A. (Ed.). (1993). Metaphor and Thought. Cambridge England: Cambridge University Press. 
Ortony, A., Reynolds, R. E., \& Arter, J. A. (1978). Metaphor: Theoretical and Empirical Research. Psychological Bulletin, 85, (5), 919-943. http://dx.doi.org/10.1037/0033-2909.85.5.919

Panavelil, A. (2011). Teaching Poetry in an EFL/ESL Class: An Integrative and Communicative Approach. ELT Voices India Journal, 1, (3), 11-20.

Petrie, H. G., \& Oshlag, R. S. (1993). Metaphor and Learning. In A. Ortony (Ed.), Metaphor and Thought (2nd ed., pp. 579-609). Cambridge England: Cambridge University Press.

Picken, J. (2007). Literature, Metaphor and the Foreign Language Learner. Basingstoke: Palgrave Macmillan.

Piquer Píriz, A. M. (2011). Figurative language at the early stages of EFL: Are trainee Primary School teachers aware of its importance? International Journal of Innovation and Leadership on the Teaching of Humanities, 1, (1), 80-98.

Richards, I. A. (1965). The Philosophy of Rhetoric. London: Oxford University Press.

Ricoeur, P. (1978). The Rule of Metaphor: Multi-disciplinary Studies of the Creation of Meaning in Language. (R. Czerny, Tran.). Toronto; Buffalo; London: University of Toronto Press.

Rodríguez, L. F. G. (2018). English Learners' Voices on Integrating Poetry through a Transactional Approach in an EFL Classroom. Literatura y Lingüística, (37), 355-380.

Savvidou, C. (2004). An Integrated Approach to Teaching Literature in the EFL Classroom (TESL/TEFL). The Internet TESL Journal, X(12). Retrieved from http://iteslj.org/Techniques/Savvidou-Literature

Searle. (1979). Expression and Meaning. Cambridge: Cambridge University Press.

Sepp, H. R., \& Embree, L. (2010). Handbook of Phenomenological Aesthetics. London \& New York: Springer Science \& Business Media.

Srisermbhok, A. (2017). Using Poetry to Enhance Learners' Communication Skills. The New English Teacher, 11, (1), 120.

Stern, J. (2000). Metaphor in Context. Cambridge, Mass: A Bradford Book.

Stockwell, P. (2005). Cognitive Poetics: An Introduction. London \& New York: Routledge.

Wan, W., \& Low, G. (Eds.). (2015). Elicited Metaphor Analysis in Educational Discourse. Amsterdam, Netherlands ; Philadelphia: John Benjamins Publishing Company.

Wheelwright, P. E. (1962). Metaphor and Reality. United States of America: Indiana University Press.

Widdowson, H. G. (1975). Stylistics and the Teaching of Literature. London: Longman.

Yavuz, A. (2010). Enhancing Creativity in the Communicative Language Classroom through Poetry as a Literary Genre. Dil Dergisi, (149), 64-79.

Zheng, H., \& Song, W. (2010). Metaphor Analysis in the Educational Discourse: A Critical Review. (Chris \& Suky, Eds.)US-China Foreign Language, 84, 8, (9), 42-49 


\section{Appendix A. Poetic Teaching Materials}

\section{William "Daffodils" \\ Wordsworth's \\ I wandered lonely as a cloud \\ That floats on high o'er vales and hills, \\ When all at once I saw a crowd,} A host, of golden daffodils; Beside the lake, beneath the trees, Fluttering and dancing in the breeze.

Continuous as the stars that shine And twinkle on the milky way, They stretched in never-ending line

Along the margin of a bay: Ten thousand saw I at a glance, Tossing their heads in sprightly dance.

The waves beside them danced; but they

Out-did the sparkling waves in glee:

A poet could not but be gay, In such a jocund company: I gazed--and gazed--but little thought

What wealth the show to me had brought:

For oft, when on my couch I lie

\section{James Weldon Johnson's "The Glory of the Day Was in Her Face"}

The glory of the day was in her face, The beauty of the night was in her eyes
In vacant or in pensive mood, They flash upon that inward eye Which is the bliss of solitude; And then my heart with pleasure fills, And dances with the daffodils

\section{Robert Burns" "A Red, Red Rose"}

O my Luve's like a red, red rose

That's newly sprung in June;

O my Luve's like the melodie

That's sweetly played in tune.

As fair art thou, my bonnie lass, So deep in luve am I;

And I will luve thee still, my dear, Till a' the seas gang dry:

Till a' the seas gang dry, my dear, And the rocks melt wi' the sun;

I will luve thee still, my dear, While the sands o' life shall run.

And fare thee weel, my only Luve, And fare thee weel awhile! And I will come again, my Luve, Tho' it ware ten thousand mile.

\section{Anne Bradstreet's “To My Dear and Loving Husband"}

If ever two were one, then surely we. If ever man were loved by wife, then thee.

If ever wife was happy in a man, Compare with me, ye women, if you can.

I prize thy love more than whole mines of gold, 
And over all her loveliness, the grace

Of Morning blushing in the early

skies.

And in her voice, the calling of the

dove;

Like music of a sweet, melodious

part.

And in her smile, the breaking light of love;

And now the glorious day, the

beauteous night,

The birds that signal to their mates at

dawn,

To my dull ears, to my tear-blinded

sight

Are one with all the dead, since she is gone.
Or all the riches that the East doth hold.

My love is such that rivers cannot quench,

Nor ought but love from thee give recompense.

Thy love is such I can no way repay;

The heavens reward thee manifold, I pray.

Then while we live, in love let's so persever,

That when we live no more, we may live ever

\section{Appendix B. The Pretest}

Name: Group

(Time allotted: $2 \mathrm{~h}$ )

\section{First Rubric (Figurative Comprehension)}

Exercise 01: State if the following statements are literal or figurative (figure out which type is being used): (10pts)

1. if ever two were one

2. so deep in love am I

3. ten thousand saw I at a glance

4. the beauty of the night was in her eyes

5. for oft, when on my couch I lie

6. I will come again, my luve

7. are one with all the dead

8. the rocks melt with the sun

9. melodie that's sweetly played in tune

10. a poet could but be gay

Exercise 02: categorize the following metaphors under conceptual domains (10pts)

11. since she is gone (DEATH IS ...................)

12. the breaking light of love (LOVE IS ...............)

13. the waves beside them danced (DANCE IS .................)

14. the heavens reward thee manifold (HEAVEN IS .............)

15. my heart with pleasure fills (HEART IS A ......................) 


\section{Second Rubric (Figurative Interpretation) (10pts)}

Exercise 01: paraphrase the sentences below turning them from figurative to literal:

17. And I will love thee still, my dear/ Till all the seas gang dry

18. And in her voice, the calling of the dove

19. I wandered lonely as a cloud / That floats on high o'er vales and hills

20. While the sands of life shall run

21. My love is such that rivers cannot quench (drink so that no more you feel thirsty)

Exercise 02: complete the following words to create metaphors (10pts)

22. My love is

23. The morning is

24. Her smile

25. I wandered as

26. The birds

27. Third Rubric (Figurative Evaluation)

28. Select 05 metaphors from the poetic works under study, then evaluate them in terms of richness, compatibility, worthiness of reading, creativity, imagination, and emotive effect (please justify your answers): (10pts)

\begin{tabular}{|c|c|c|c|c|c|c|}
\hline \multirow[b]{2}{*}{$\begin{array}{c}\text { Metap } \\
\text { hor } \\
\text { s }\end{array}$} & \multicolumn{2}{|c|}{ Aesthetic } & Evaluation & \multicolumn{3}{|c|}{ Emotional Evaluation } \\
\hline & $\begin{array}{l}\mathrm{R} \\
\mathrm{i} \\
\mathrm{c} \\
\mathrm{h}\end{array}$ & $\begin{array}{r}\text { Compa } \\
\text { tible }\end{array}$ & $\begin{array}{r}\text { Worth } \\
\text { Rea } \\
\text { ding }\end{array}$ & $\begin{array}{r}\text { Crea } \\
\mathrm{ti} \\
\mathrm{v} \\
\mathrm{e}\end{array}$ & $\begin{array}{c}\text { Imagin } \\
\text { ativ } \\
\mathrm{e}\end{array}$ & $\begin{array}{r}\text { Emo } \\
\text { ti } \\
\mathrm{v} \\
\mathrm{e}\end{array}$ \\
\hline & & & & & & \\
\hline & & & & & & \\
\hline & & & & & & \\
\hline & & & & & & \\
\hline
\end{tabular}

Arab World English Journal for Translation \& Literary Studies 
29. Explain whether the many metaphors that embody the theme of 'love'-used differently by each poet - have added any strength, genuineness, novelty, artistic beauty, or elicitation to the values and intentions of the poems. (10pts)

1. Appendix C. The Posttest

Appendix C. The Posttest

Name:

Rubric (A) Comprehension

Exercise 01: Extract from each poem two figures of speech, and then state their type:

30. Anne Bradstreet's “To My Dear and Loving Husband”

2. William Wordsworth's "Daffodils

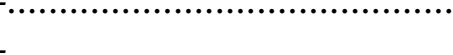

3. James Weldon Johnson's "The Glory of the Day Was in Her Face”

$$
- \text {..... }
$$

4. Robert Burns's “A Red, Red Rose”

Arab World English Journal for Translation \& Literary Studies 
Exercise 02: State if these expressions are truly figurative or literal (write the type of the figurative expression)

31. I prize thy love more than whole mines of gold ( literal)

32. Wife was happy in a man (literal)

33. The glory of the day was in her face (figurative)

34. And dances with the daffodils (literal)

35. I will love thee still (figurative)

36. Along the margin of a bay (literal)

37. Till a' the seas gang dry, my dear (figurative)

38. In her smile, the breaking light of love (literal)

39. If ever two were one (figurative)

40. All the riches that the East doth hold (figurative)

41. I will come again, my love (literal)

42. Ten thousand saw I at a glance (literal)

\section{Rubric (B): Interpretation}

\section{Exercise 01: Choose the most appropriate interpretation}

43. The beauty of the night was in her eyes.

a) The woman's eyes are brightly black $\square$, b) The eyes of the woman have the eyes of the night $\square$, c) The woman's eyes are sad and gloomy $\square$

44. The heavens reward thee manifold

a) Heavens are people of many traits $\square$, b) many heavens will give you a recompense in a multiplicity of ways $\square$, c) I pray for 'You' to be rewarded heavens on earth which give you all sorts of pleasure and happiness

45. In her voice, the calling of the dove

a) She starts to speak when the dove calls her $\square$, b) She has the sound of dove in her voice $\square$, c) Her voice is sweet and soft, that it is compared to the nice twitter of the dove

46. Tossing their heads in sprightly dance

a) Daffodils have heads that dance in the party $\square$, b) The flowers swing by the breeze as if they are persons that move and dance cheerfully $\square$, c) Flowers lost their heads when they dance happily

47. My Luve's like a red, red rose / That's newly sprung in June:

a) Poet's love is red in colour that looks like a rose $\square$, b) Poet's love is fresh and gives nice feelings, so that is compared to a red rose that grows in summer $\square$, c) Poet loves the red roses a lot, especially those are seeded in summer

\section{Exercise 02: translate the following verses imbued with metaphors into the Standard Arabic}

48. I will luve thee still, my dear/ While the sands o' life shall run.

49. That when we live no more, we may live ever.

50. And over all her loveliness, the grace/ of Morning blushing in the early skies.

51. Ten thousand saw I at a glance/ Tossing their heads in sprightly dance.

52. Oh my Luve's like the melodie/ that's sweetly played in tune

Rubric (C): Evaluation

Arab World English Journal for Translation \& Literary Studies 
AWEJ for Translation \& Literary Studies Volume, 4 Number 2 May 2020

Resurrecting 'Metaphor' inside the EFL Poetry Classroom

Bouali

Exercise 01: re-read William Wordsworth's "Daffodils" in order to finish the following conceptual metaphors, then demonstrate their worthiness in the poem.

53. EYE IS

54. COMPANY IS

55. DAFFODILES ARE

56. DANCE IS

Exercise 02: compare in a short paragraph Robert Burns, Anne Bradstreet and James Weldon Johnson implication of poetic metaphors to portray the theme of love, and explain which images you consider are more powerful to embody the true feelings (tone) of the poet.

Arab World English Journal for Translation \& Literary Studies

ISSN: 2550-1542 | www.awej-tls.org 